\title{
LIN54 Gene
}

National Cancer Institute

\section{Source}

National Cancer Institute. LIN54 Gene. NCI Thesaurus. Code C162421.

This gene plays a role in both DNA binding and the regulation of cell cycle arrest. 